\title{
Temporal Variation of Surface Water Quality in the Swan River Catchment in Himachal Pradesh India
}

\author{
Avinash Kumar Sharda, Harish Chander Sharma \\ and Brij Bhushan
}

\begin{abstract}
As industrial growth in the lower Shiwalik hills has risen in past two decades, the last 10 years in the Una district has seen a rapid development in industrial and urban growth due to grant of industrial package by the central government of India. As a result, several production plants have sprung up within the Swan River catchment, threatening the water quality of this area. However, the actual effects on water quality are heretofore unknown. In this paper, we assess the water quality of the Swan River catchment by calculating the National Sanitation Foundation Water Quality Indicators (NSFWQI) and Overall Index of Population (OIP) between 2003-2012. Data on monitored cross sections were collected from State Pollution Control Board of Himachal Pradesh, India. The results indicate that there has been recent (within five years) considerable improvement in the water quality due to enforcement of proper pollution control technologies. The relationship between economic growth (GDP) and water quality was also studied.
\end{abstract}

We carried out regression analysis of the water quality data to determine significant parameters as independent variables and WQI and OIP as dependent variables. The regression analysis further identified that the contribution of each variable with significant values $r=0.733, R 2=0.695$. The study further suggests that sustainable development is possible through adoption of proper treatment technologies, enforcement of formal legislation, and preparation of remedial action plans to reduce the environmental stresses.

Keywords: Pollution, Swan River, Overall Index of Population, India.

\section{Introduction}

Development through industrialization brings increased rates of pollution. Often times environmental regulations will be relaxed so as to induce better economic growth, but at cost to the purity of natural resources and standard of living.

$\mathrm{Li}$ Yong et al. (2005) reported that surface waters in Suzhou region were found unsuitable for drinking purposes after a long period of industrial growth in the region. Wang et al. (2007) found temporal variations of surface water quality in urban, suburban and rural areas during rapid urbanization in Shanghai, an economic and financial centre of China.

Teng et al. (2011) studied the impact of urbanization and industrialization on surface water quality in Panzhihua (Sichuan Province) and reported an increase in effluent bearing heavy metals causing degradation of water quality. They suggested policy measures such as adjusting industry structures, optimizing the clean technology, and controlling pollution sources. Brilley et al. (2006) reported that industrialization can impact the entire hydrological process due to its potential to change land use patterns, population density, and watershed coverage.

But industrialization and development alone are not sufficient explanations for water quality changes. Seasonal variations of temperature and rainfall also play a role.

In the Dehradun district of Uttarakhand, India, Bartarya et al. (2012) reported that ion concentration in surface water is higher in the summer as compared to the monsoon period, indicating the effect of elevated temperature, increased evaporation and absence of recharge during the low water level period of pre monsoon season. Cronin et al. (2003) studied the temporal variations in depth-specific hydro-chemistry and sewage-related microbiology in an urban sandstone aquifer in Nottingham, England. The authors reported low levels of microbial contamination should be expected at depths in fissured sand stone due to aquifer heterogeneities such as fissuring and the occurrence of sand stone bands.

It is equally important to have the proper toolkit to study changing water quality over time. Shrestha et al. (2007) assessed surface water quality using multivariate statistical techniques, including Cluster Analysis (CA), Principal Component Analysis (PCA), Factor Analysis (FA) and Discriminal Analysis (DA). Working in the Fuji River basin, they worked out large water quality data sets for 12 parameters for the years 1995-2002. Mustapha et al. (2012) used robust statistical tools to water quality datasets to determine the most significant parameters regarding temporal water quality variations. These two studies informed our methods for the present study.

The Swan River is an appropriate site for our study because the river runs through an area of Himachal Pradesh in India that has experienced rapid industrial growth in the past 50 years, including steel, pharmaceuticals, and fermentation products. All of these initiatives were supported by the Indian government.

As a result of industrialization and urbanization, the environmental pollutants found in most of the surface waters in the Swan River catchment have been deemed not suitable for drinking in both the rural and urban areas, and force them to exploit ground water resources. In order to study the relationship between economic development and environmental pollution on the Swan River, we collected water quality data for 2003 to 2012 and evaluated the Water Quality Indices, which were used to characterize temporal variation of Swan 
River surface water quality during a period of industrial and urban growth in the catchment.

\section{Study Area}

The Swan River, also known as the River of Sorrow and a tributary of the Sutlej River, flows from the north in a south westerly direction. Swan River Flood Management and Integrated Development (SRFMID) has implemented controls for the flood hazards, which has made the river more usable to the people of the Una district, Himachal Pradesh. Major towns located on the banks of river Swan include Gagret, Una, Mehatpur and Santokhgargh. Each of these locations feature heavy industrial areas.

The total length of the Swan is approximately 85 kilometers, of which 65 fall in Himachal Pradesh. The total catchment area of the river watershed is $1400 \mathrm{~km}^{2}$ with 80 tributaries contributing to the flow during monsoon. The Swan is an intermittent river and maintains base flow in the lower reaches. Eighty percent of its catchment area falls in Una district and the river divides the district into two parts. The river is the main source of sub-soil water in the catchment for domestic, industrial and irrigation (Venu \& Madhvri, 2011).

The Swan River passes through three industrially developed areas: 49 are medium-sized units and 575 small-scale. The SRFMID Project was formulated by to reclaim the land by providing embankments on both sides for fishery development, flood control and water utilization. Irrigation and Public Health (IPH) department in order

In the light these increased human activities on the Swan River, it becomes necessary to evaluate the river water quality. What follows is our study of the relationship between WQIs and population and industrial growth by assessing surface water quality using different methods calculation of different indices between period 2003 to 2012. From this analysis, we suggest implementation of formal regulations and enforcement of proper pollution control measures.

\section{Materials and Methods}

The water quality data (Table 1) for the last 10 years was used along with water quality indices estimated by National Sanitation Foundation Method Water Quality Index (NSFWQI) and Overall Index of Pollution (OIP). These figures were calculated by taking into consideration various parameters: Temp (o C), $\mathrm{pH}, \mathrm{DO}(\mathrm{mg} / \mathrm{l}), \mathrm{BOD} 5$ (mg/l), Turbidity (NTU), MPN, TDS (mg/l), NO3-N (mg/l), Total Phosphate (mg/l), Hardness (mg/l) and Fluoride (mg/l).

Following methods have been used for evaluating water quality indices.

National Sanitation Foundation Water Quality Index (NSFWQI) for estimating water quality of any water body and is mathematically expressed as;

$$
\mathrm{WQI}=\sum \mathrm{WiQi}
$$

Where $\mathrm{Q} i=$ Sub Index of ith water quality parameter

$\mathrm{Wi}=$ Weight (in terms of importance) associated with water quality parameter parameters

$\mathrm{N}=$ Number of water quality

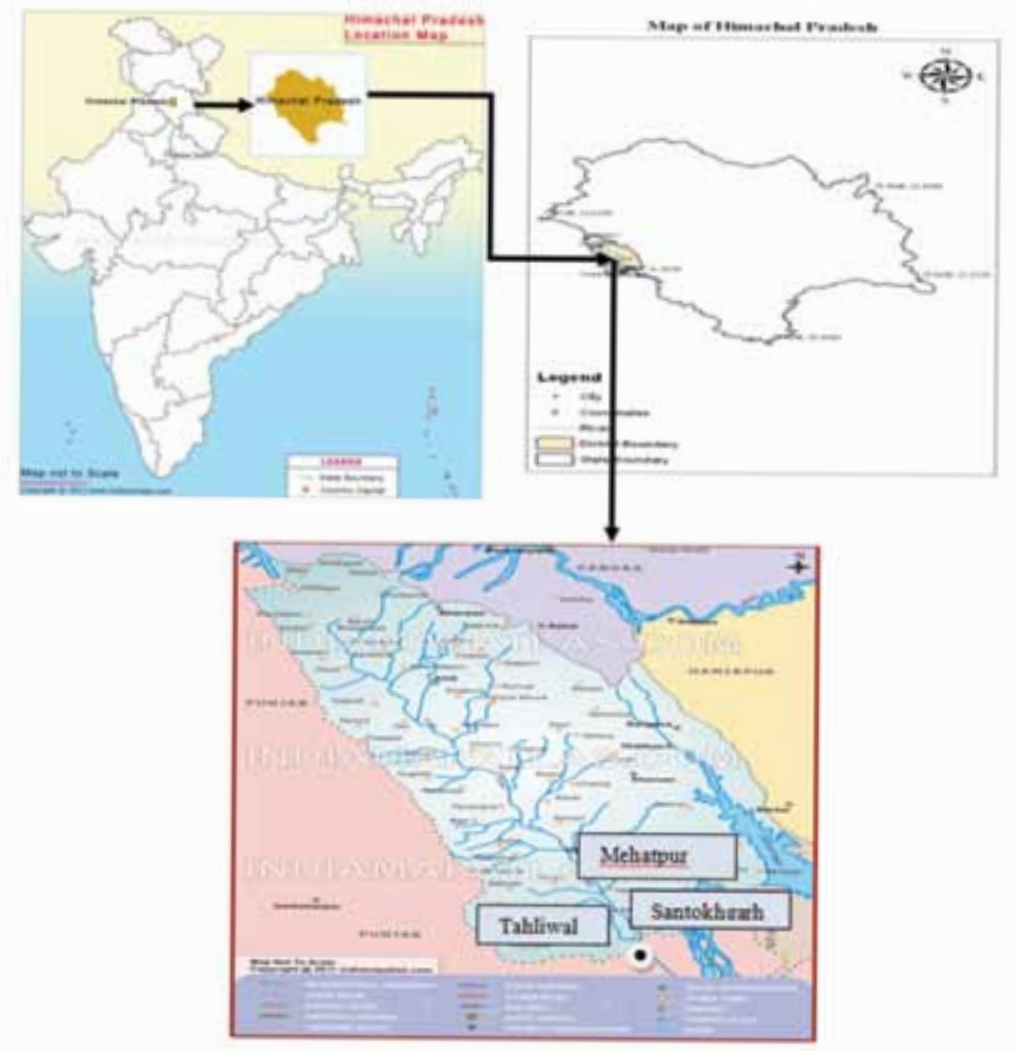

Figure1: Location Map of Swan River catchment and study sampling location
We calculated 42 NSFWQI using software downloaded from the website http://www.swrp.esr.pdu.edu. NSF WQI Water Quality ratings based on the Water Quality Index per sub index function for parameters on 100 point scale are presented in Table- 1.

\section{Overall Index of Pollution (OIP)}

Different water quality parameters were measured in different units of measurement. Hence, it is necessary to translate them into commensurate units so that integrated indices can be obtained and used in decisionmaking. An integer value in geometric progression (e.g., 1, 2, 4, 8, 16) to each of class $\left(\mathrm{C}_{1}, \mathrm{C}_{2}, \mathrm{C}_{3}, \mathrm{C}_{4}\right.$ and $\left.\mathrm{C}_{5}\right)$ is assigned. Where the number termed as class index indicating level of pollution. This forms the basis for comparison of water quality from "excellent" to "heavily polluted." The limits and ranges for different parameters have been shown in Table 1. OIP is estimated as the average of all the pollution indices (Pi) for individual water quality parameters considered and is given by the mathematical expression. 
$\mathrm{OIP}=\sum \mathrm{iPi} / \mathrm{n}$

Where $\mathrm{Pi}=$ pollution index for ith parameter. $\mathrm{i}=1,2,--$ ,$---- n$ and $n=$ number of parameters.

The pollution index $(\mathrm{Pi})$ is obtained for each parameter by using mathematical expressions developed by Saragaonkar and Deshpande (2003) and further using value function curves.

\begin{tabular}{|c|c|c|c|c|c|}
\hline \multicolumn{5}{|c|}{ Water Quality Index } \\
\hline Range & $90-100$ & $70-90$ & $50-70$ & $25-50$ & $0-25$ \\
\hline Quality & Excellent & Good & Medium & Bad & Very bad \\
\hline
\end{tabular}

Table1: NSFWQI Limits

The interpretation of OIP values to determine the pollution status is calculated the same was as we calculate individual parameters (discussed above). The OIP is simple to estimate and flexible to the addition or deletion of parameters. However, comparative assessment of water quality at different places or at different times can be made only when parameters included in the OIP are the same. Accordingly, recommendations may be made regarding the specific use of water. The numerical estimates of OIP correspond to classes shown in Table 2.

\begin{tabular}{|c|c|c|c|}
\hline S.No & Range & Category & Class \\
\hline 1 & $0-1$ & Excellent & $\mathrm{C}_{1}$ \\
\hline 2 & $1-2$ & Acceptable & $\mathrm{C}_{2}$ \\
\hline 3 & $2-4$ & Slightly Polluted & $\mathrm{C}_{3}$ \\
\hline 4 & $4-8$ & Polluted Class & $\mathrm{C}_{4}$ \\
\hline 5 & $8-16$ & Heavily Polluted & $\mathrm{C}_{5}$ \\
\hline
\end{tabular}

Source - A. Saragaonkar, Deshpande., 2003: Development of Overall Index of Pollution

Table 2: Estimation of OIP on basis of different classes

The water quality parameters (turbidity, $\mathrm{pH}$, color, DO, BOD, TDS, hardness, $\mathrm{Cl}$, SO4, total Coliform) are considered as significant indicator parameters of surface water quality for evaluating OIP. The concentrations (levels/ranges) of these parameters in the above classes are defined with due consideration of CPCB standards/ criteria and IS10500. For parameters and classes not included in the CPCB standards, reference was made to the standards defined by other agencies.

\begin{tabular}{|c|c|c|c|c|}
\hline Year & WQI & Rating & OIP & Classes \\
\hline 2003 & 54.82 & Medium & 2.62 & Slightly Polluted \\
\hline 2004 & 72.4 & Good & 1.78 & Acceptable \\
\hline 2005 & 62.33 & Medium & 2.48 & Slightly Polluted \\
\hline 2006 & 67.58 & Medium & 2.22 & Slightly Polluted \\
\hline 2007 & 65.7 & Medium & 2.22 & Slightly Polluted \\
\hline 2008 & 69.53 & Medium & 2.06 & Slightly Polluted \\
\hline 2009 & 70.11 & Good & 1.91 & Acceptable \\
\hline 2010 & 67.62 & Medium & 2.09 & Slightly Polluted \\
\hline 2011 & 72.69 & Good & 1.93 & Acceptable \\
\hline 2012 & 64.36 & Medium & 2.39 & Slightly Polluted \\
\hline
\end{tabular}

Table 4: Summarized results of WQI and OIP for 2003-2012
The values of WQI and OIP based on average values of parameters for the period 2003-2012 AD has been summarised in Table 4.

\section{Results and Discussion}

Impact of Urbanization and Industrialization on Water Quality. The variation between WQI, urbanization level and industrial growth for the period between 2003 to 2012 is shown in Figure 2.

The WQI was $54.82 \%$ in 2003 , which was slightly above the class of water, which falls under in the bad category, indicating that steps should be taken for treating domestic sewage. The results show an increase of pollution and effluents bearing Coliforms, COD, BOD5, nitrogen and phosphorous.

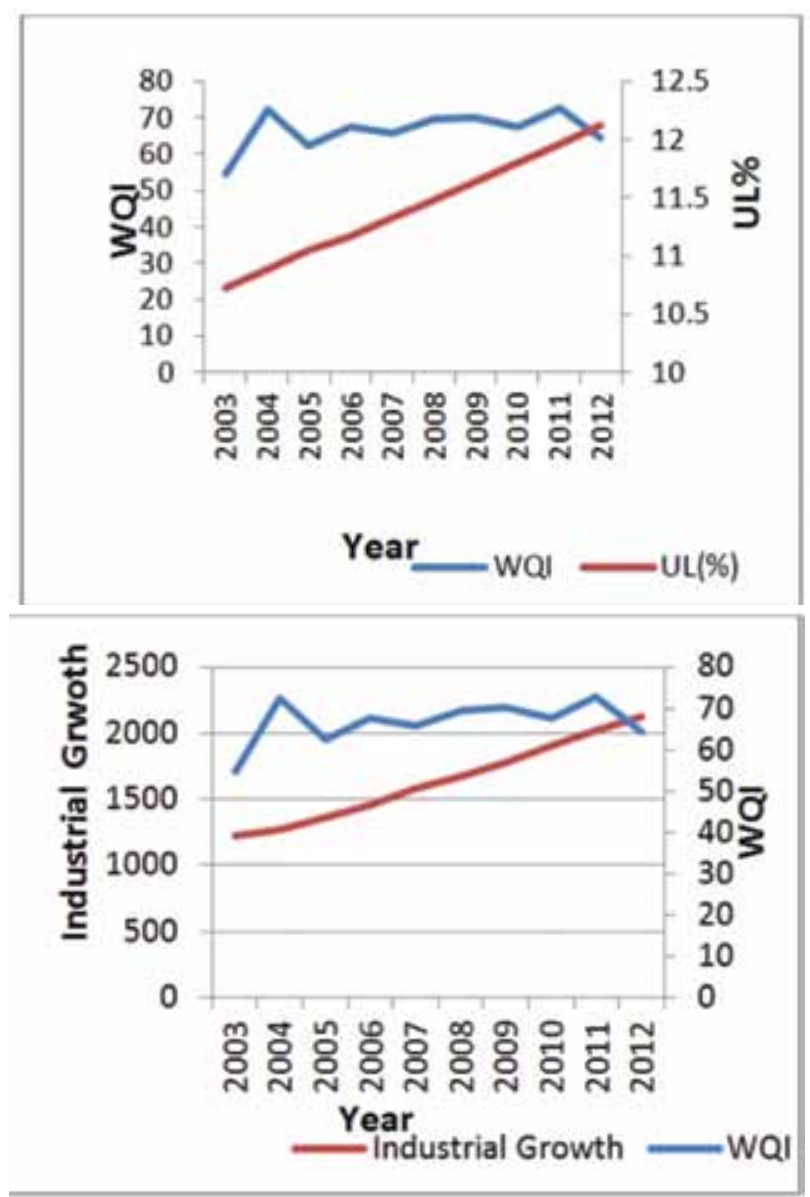

Figure 2: Relationship of WQI with UL (\%) and Industrial Growth for the period (2003-12)

The WQI improved in the consequent years up to 2011-12, showing that waste water treatment and disposal had been put into operation and the WQI improved with the increase in population. Prior industrial package grants in 2003, the value of WQI was found to fall under medium category and slightly above the bad category. In preceding years, the value of WQI varies between $62.33 \%$ and $72.69 \%$ and falls under the medium category. Maximum industrial growth took place between 2003 to 2011, and the WQI declined initially, but improved after that showing that water quality also improved due to enforcement of formal regulations 
and implementation of best available technologies that effectively improved waste water treatment in the area.

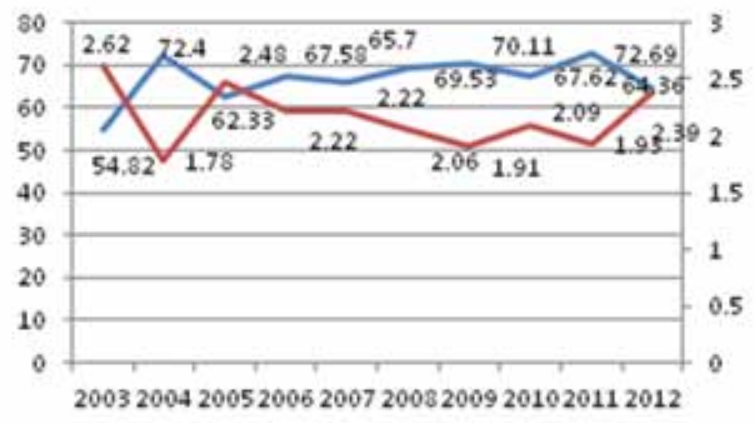

Year $\quad$ WOS OIP

Figure 3: Spatial pattern of WQI and OIP due to IL Industrialisation Level and UL Urbanization Level important parameter affecting water quality with value of $\mathrm{R} 2=0.457$ in the river followed by Nitrate $(\mathrm{R} 2=0.379)$ and Biochemical Oxygen Demand (BOD) with value of R2=0.192 as shown in Figure 4, which further shows that DO is directly in proportion with WQI, whereas $\mathrm{NO}_{3}$ and BOD varies inversely proportion to the WQI.

\begin{tabular}{|c|c|c|c|}
\hline $\begin{array}{c}\text { Independent } \\
\text { variables }\end{array}$ & Coefficient & t-ratio & p-value \\
\hline $\mathrm{pH}$ & -3.162 & -3.200 & 0.00 \\
\hline Temperature & -0.068 & -1.150 & 0.26 \\
\hline $\mathrm{DO}$ & 0.683 & 2.742 & 0.01 \\
\hline $\mathrm{BOD}$ & -0.710 & -3.879 & 0.00 \\
\hline Nitrate & -0.440 & -1.565 & 0.13 \\
\hline Total Coliform & -0.002 & -2.003 & 0.05 \\
\hline Constant & 31.120 & 3.647 & 0.00 \\
\hline
\end{tabular}

Table 6: Variables effecting River Water Quality (OIP)

\section{Evaluation of Water Quality}

Figure 3 shows the relationship between WQI and OIP in our study.

Water quality was found medium and slightly polluted in 2012 showing that untreated domestic sewage from urban centres and effluent from industrial areas were being discharged into the Swan River, and suggests that some remedial action plan is required in order to reduce environmental stresses.

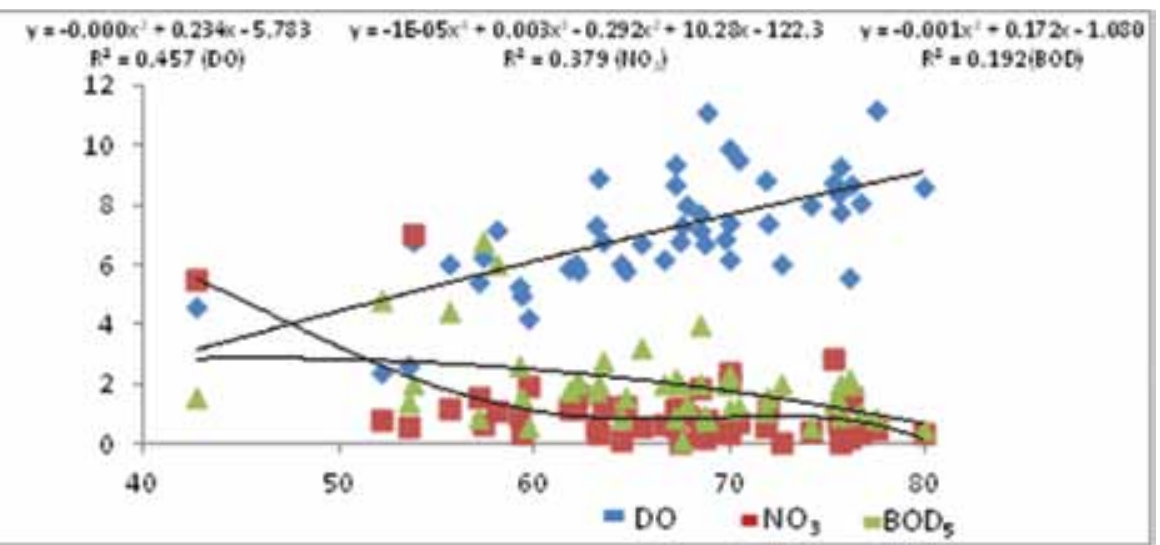

Figure 4: Polynomial fit of WQI (NSF) for the WQ data from 2003-2012

Table 6 presents the results of analysis when OIP was taken as dependent variable. The R2 values are more than estimated by NSFWQI method results. Here temperature and nitrate were found as insignificant variables affecting river water quality and among other variables again DO was found as most important variable followed by BOD and total Coliform and a close look at the Student's t-statistics or t-ratio indicated that Dissolved Oxygen (DO) was the most important parameter affecting water quality with value of $\mathrm{R} 2=0.538, \mathrm{n}=35$ in the river followed Biochemical Oxygen Demand (BOD) with value of $\mathrm{R} 2=0.484, \mathrm{n}=35$ as shown in Figure 5 .

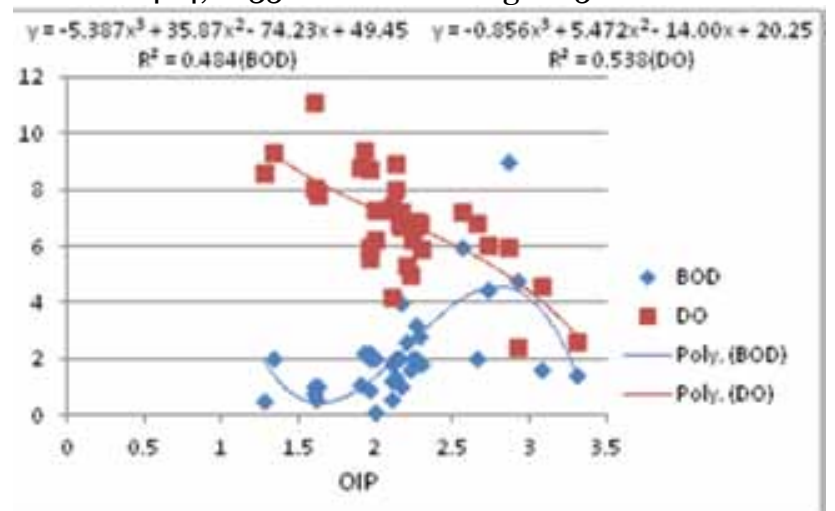

Figure 5: Polynomial fit of OIP for the WQ data from 2003-2012 
The variation between OIP and BOD shows an inverted U-shaped curve, which reflects a phase of development "pollution first treatment after".

The maximum values of BOD initially increase with OIP and lesser values decrease as OIP increases during the period 2003-2012.

\begin{tabular}{|c|c|c|c|c|}
\hline Variable & Max & Min & Mean & Std Deviation \\
\hline $\mathrm{pH}$ & 8.63 & 7.60 & 8.14 & 0.312 \\
\hline Temperature & 36.00 & 10.00 & 23.45 & 5.993 \\
\hline DO & 11.10 & 2.40 & 6.85 & 1.818 \\
\hline BOD & 14.00 & 0.10 & 2.52 & 2.642 \\
\hline Nitrate & 7.02 & 0.00 & 1.042 & 1.436 \\
\hline Total Coliform & 1800 & 32 & 296 & 484.525 \\
\hline
\end{tabular}

Table 7: Statistics of water quality parameters
Table 7 provides the descriptive statics of water quality parameters giving maximum, minimum, mean and standard deviation of the parameters mentioned.

The relative variation of $\mathrm{pH}$ and Nitrate has been observed on lower side compare to the Temperature, DO, BOD and Total Coliform, which has been found as significant parameters and should be monitored on regular basis.

Although the $\mathrm{pH}$ and temperature are important, they have been found to be insignificant and need only be observed as routine parameters.

\begin{tabular}{|c|c|c|c|c|c|c|c|c|c|c|c|c|c|c|}
\hline $\begin{array}{c}\text { Month/ } \\
\text { year }\end{array}$ & pH & $\underset{{ }^{\circ} \mathrm{C}}{\text { Temp }}$ & $\begin{array}{c}D .0 \\
(\mathrm{mg} / \mathrm{l})\end{array}$ & $\begin{array}{l}\text { BOD } \\
\mathrm{mg} / \mathrm{I}\end{array}$ & $\begin{array}{c}\text { Tur- } \\
\text { bidity }\end{array}$ & $\mathrm{PO}_{4}$ & $\mathrm{NO}_{3}-\mathrm{N}$ & $\begin{array}{c}\text { F.C } \\
\text { MPN/ } \\
100 \mathrm{ml}\end{array}$ & $\begin{array}{c}\text { T.C } \\
\text { MPN/ } \\
100 \mathrm{ml}\end{array}$ & $\begin{array}{c}\text { E.Coli } \\
\text { MPN/ } \\
100 \mathrm{ml}\end{array}$ & WQI & Ratings & OIP & Ratings \\
\hline Mar-03 & 8.54 & 20 & 6.8 & 2 & 14 & NA & 7.02 & 780 & 1800 & 1170 & 53.83 & Medium & 2.66 & $\begin{array}{l}\text { Slightly Pol- } \\
\text { luted }\end{array}$ \\
\hline Jun-03 & 7.78 & 30 & 4.6 & 1.6 & 104 & NA & 5.545 & 780 & 1790 & 1170 & 42.74 & Bad & 3.08 & $\begin{array}{l}\text { Slightly Pol- } \\
\text { luted }\end{array}$ \\
\hline Dec-03 & 8.2 & 15 & 8.9 & 2 & 9.5 & NA & 0.325 & 600 & 1760 & 900 & 63.28 & Medium & 2.13 & $\begin{array}{l}\text { Slightly Pol- } \\
\text { luted }\end{array}$ \\
\hline Mar-04 & 8.27 & 24 & 7.8 & 1 & 3 & NA & 0.086 & 40 & 110 & 60 & 75.56 & Good & 1.63 & Acceptable \\
\hline Jun-04 & 7.71 & 28 & 4.2 & 0.6 & 22 & NA & 1.922 & 40 & 110 & 60 & 59.71 & Medium & 2.11 & $\begin{array}{l}\text { Slightly Pol- } \\
\text { luted }\end{array}$ \\
\hline Oct-04 & 8.42 & 23 & 8 & 0.6 & 20 & NA & 0.415 & 22 & 80 & 33 & 74.1 & Good & 1.61 & Acceptable \\
\hline Apr-05 & 7.76 & 23 & 2.6 & 14 & 9 & NA & 0.6 & 70 & 200 & 102 & 53.61 & Medium & 3.3 & $\begin{array}{l}\text { Slightly Pol- } \\
\text { luted }\end{array}$ \\
\hline Jul-05 & 8.39 & 26.5 & 6.8 & 2 & 6 & NA & 0.07 & 140 & 240 & 196 & 67.36 & Medium & 2.15 & $\begin{array}{l}\text { Slightly Pol- } \\
\text { luted }\end{array}$ \\
\hline Oct-05 & 8.1 & 24 & 7.3 & 0.1 & NA & NA & 1.2 & 160 & 280 & 223 & 67.52 & Medium & 2 & $\begin{array}{l}\text { Slightly Pol- } \\
\text { luted }\end{array}$ \\
\hline Jan-06 & 7.95 & 18 & 8.7 & 0.9 & 18 & NA & 1.188 & 120 & 400 & 176 & 67.22 & Medium & 1.96 & Acceptable \\
\hline Apr-06 & 8.58 & 32.5 & 7.3 & 1.8 & 8 & NA & 0.54 & 60 & 240 & 87 & 63.16 & Medium & 2.1 & $\begin{array}{l}\text { Slightly Pol- } \\
\text { luted }\end{array}$ \\
\hline Jul-06 & 8.34 & 34 & 7.2 & 6 & NA & NA & 1.1 & 56 & 160 & 81 & 58.04 & Medium & 2.56 & $\begin{array}{l}\text { Slightly Pol- } \\
\text { luted }\end{array}$ \\
\hline Oct-06 & 7.96 & 24 & 6.7 & 3.2 & NA & NA & 0.589 & 100 & 300 & 147 & 65.5 & Medium & 2.26 & $\begin{array}{l}\text { Slightly Pol- } \\
\text { luted }\end{array}$ \\
\hline Jan-07 & 8.43 & 14 & 11.1 & 0.8 & NA & NA & 0.8 & 52 & 130 & 76 & 68.8 & Medium & 1.6 & Acceptable \\
\hline Apr-07 & 7.82 & 32 & 6.8 & 2.8 & 1.4 & 0.23 & 1.28 & 46 & 180 & 71 & 63.48 & Medium & 2.28 & $\begin{array}{l}\text { Slightly Pol- } \\
\text { luted }\end{array}$ \\
\hline Jul-07 & 8.37 & 36 & 5 & 1.6 & NA & NA & 0.36 & 56 & 220 & 83 & 59.38 & Medium & 2.22 & $\begin{array}{l}\text { Slightly Pol- } \\
\text { luted }\end{array}$ \\
\hline Oct-07 & 8.63 & 26.5 & 2.4 & 4.8 & NA & NA & 0.824 & 50 & 180 & 70 & 52.2 & Medium & 2.92 & $\begin{array}{l}\text { Slightly Pol- } \\
\text { luted }\end{array}$ \\
\hline Jan-08 & 8.01 & 10 & 9.4 & 2.2 & NA & NA & 0.55 & 64 & 160 & 86 & 67.2 & Medium & 1.92 & Acceptable \\
\hline Jul-08 & 8.36 & 22 & 6.9 & 2 & NA & NA & 0.42 & 50 & 220 & 79 & 69.71 & Medium & 2.26 & $\begin{array}{l}\text { Slightly Pol- } \\
\text { luted }\end{array}$ \\
\hline Oct-08 & 8.07 & 24 & 6.2 & 2 & NA & NA & 0.69 & 38 & 150 & 65 & 66.66 & Medium & 2 & $\begin{array}{l}\text { Slightly Pol- } \\
\text { luted }\end{array}$ \\
\hline Jan-09 & 7.6 & 20 & 9.3 & 2 & NA & NA & 0.48 & 42 & 140 & 69 & 75.57 & Good & 1.34 & Acceptable \\
\hline
\end{tabular}




\begin{tabular}{|c|c|c|c|c|c|c|c|c|c|c|c|c|c|c|}
\hline Apr-09 & 8.27 & 23 & 8.6 & 0.5 & 0.6 & 0.23 & 0 & 9 & 32 & 15 & 80.08 & Good & 1.28 & Acceptable \\
\hline Jul-09 & 7.84 & 17 & 6 & 9 & NA & NA & 0.114 & 22 & 80 & 31 & 64.44 & Medium & 2.86 & $\begin{array}{l}\text { Slightly Pol- } \\
\text { luted }\end{array}$ \\
\hline Oct-09 & 8.63 & 18.5 & 6.7 & 1 & NA & NA & 0.212 & 44 & 100 & 57 & 68.72 & Medium & 2.16 & $\begin{array}{l}\text { Slightly Pol- } \\
\text { luted }\end{array}$ \\
\hline Jan-10 & 8.5 & 18.5 & 6.2 & 2 & NA & NA & 0.341 & 18 & 60 & 26 & 69.95 & Medium & 2.24 & $\begin{array}{l}\text { Slightly Pol- } \\
\text { luted }\end{array}$ \\
\hline Apr-10 & 7.67 & 27 & 5.6 & 2.2 & NA & NA & 0.19 & 4 & 36 & 9 & 76.02 & Good & 1.96 & Acceptable \\
\hline Jul-10 & 7.74 & 31 & 5.3 & 2.6 & NA & 0.46 & 1 & 26 & 72 & 45 & 59.25 & Medium & 2.2 & $\begin{array}{l}\text { Slightly Pol- } \\
\text { luted }\end{array}$ \\
\hline Oct-10 & 8.03 & 28 & 6 & 2 & NA & NA & 0.018 & 10 & 32 & 16 & 72.67 & Good & 1.96 & Acceptable \\
\hline Jan-11 & 7.77 & 21 & 8.05 & 1.05 & NA & 0.22 & 0.359 & 13 & 126 & 19 & 76.69 & Good & 1.6 & Acceptable \\
\hline Apr-11 & 7.98 & 22.66 & 7.43 & 1.2 & 8.97 & 0.73 & 2.415 & 12 & 151.33 & 17 & 69.99 & Medium & 2.1 & $\begin{array}{l}\text { Slightly Pol- } \\
\text { luted }\end{array}$ \\
\hline Jul-11 & 8.39 & 29 & 8.03 & 1.36 & 7.5 & 0.58 & 0.933 & 16.33 & 99 & 27 & 67.71 & Medium & 2.13 & $\begin{array}{l}\text { Slightly Pol- } \\
\text { luted }\end{array}$ \\
\hline Oct-11 & 8.29 & 17.66 & 8.83 & 1.1 & 12.03 & 0.85 & 0.62 & NA & NA & NA & 71.78 & Good & 1.9 & Acceptable \\
\hline Jan-12 & 7.85 & 20.66 & 7.2 & 4 & 8.73 & 0.93 & 1.887 & NA & NA & NA & 68.48 & Medium & 2.16 & $\begin{array}{l}\text { Slightly Pol- } \\
\text { luted }\end{array}$ \\
\hline Apr-12 & 8.09 & 24.5 & 5.9 & 1.8 & 29.75 & 0.47 & 1.2 & 40 & 72 & 63 & 61.79 & Medium & 2.3 & $\begin{array}{l}\text { Slightly Pol- } \\
\text { luted }\end{array}$ \\
\hline Jul-12 & 8.57 & 16 & 6.05 & 4.45 & 34.2 & 0.55 & 1.18 & 45 & 78.5 & 71 & 55.69 & Medium & 2.73 & $\begin{array}{l}\text { Slightly Pol- } \\
\text { luted }\end{array}$ \\
\hline
\end{tabular}

Table 3: WQI and OIP-based on Water Quality Data for the period (2003-2012)

\section{Conclusion}

In the paper, we analysed the NSFWQI and OIP in surface water quality across temporal variations for the Swan River between 2003-2012. The results indicate that the surface water quality falls into the medium and slightly polluted category in 2002, 2004 and 2012. This indicates that some sources of pollution were not controlled effectively. In the other years we studied, the water quality falls under "good" and "acceptable" categories indicating that enforcement of formal regulations had helped to improve water quality.

Multiple linear regression identifies DO and Nitrate as independent variables with significant value of $r=0.676$, 0.615 and $\mathrm{R} 2=0.457,0.379$ ( $\mathrm{p}<0.05$ ), respectively, for WQI as a dependent variable. In case of OIP, the role of each variable with $\mathrm{DO}$ and BOD as independent parameters is significant with values $\mathrm{r}=0.733,0.695$ and $\mathrm{R} 2=0.538,0.484(\mathrm{p}<0.05)$, respectively. The tools used for statistical analysis provide the objective of stressor parameters and from where it is clear that DO, BOD and $\mathrm{NO}_{3}$ were found to be the most significant parameters responsible for water quality variation in Swan River.

As our study is confined to limited stretch of the river, we suggest that segment-wise analysis along different stretches could be done for control of stressor parameters. We suggest further that for sustainable development, measures such as environmental planning, total discharge control volume, and polluter-pays principle should be implemented to improve surface water quality.

\section{References}

APHA : (2005) Standard methods for the examination of water and waste water, 21st edition, American Public Health Association, Washington.

Brilly, M., Rusjan, S., Widmar, A., (2006). Monitoring the Impact of Urbanization on the Glinscica Stream. Physics and Chemistry of the Earth, 31(17):1089-1096

Bartarya, S. K., Bahukhandi, D. K., (2012) Impact Assessment of Urbanization and Industrialization on Surface and Ground Water Quality. Global Journal of Engineering Design \& Technology, 1(1):11-22

Cronin, A. A., Taylor, R. G., Powell, K. L., Barett., M. H., (2003). Temporal Variation in the depth specific hydro-chemistry and sewage related micro-biology of an urban sand stone aquifer, Nottingham. Journal of Hydro-Geology, 11 (2):205-216

Jerome, C and Pius A, (2010) Evaluation of water quality index and its impact on quality of life in an industrial area in Banglore, South India, American Journal of Scientific and Industrial Research ., 1(3): 595-603

Leblanc, R. T., Brown, R. D., Fitz Gibbon, J. E., (1997). Modelling the effect of Land Use Change on the Water Temperature in Unregulated Urban Streams. Journal of Environmental Management, 49(4):445-469

Mustapha, Adamu., Aris, A. Z., Ramli, M.F., Juahir, Hafizan.,(2012). Temporal Aspect of Surface Water Quality Variation Using Robust Statistical Tools. Scientific World Journal: 1-9

Prati, L., Pavanello, R and Pesarin, F (1971). Assessment of surface water quality by single index of pollution, Journal of water resources ., 5: 741-751 
Sargaonkar, A and Deshpandey, V (2003) Development of an Overall Index of Pollution for surface water classification scheme in Indian Context, Environmental Monitoring and Assessment., 89: 43-67

Sharma, M. P., Singal, S. K., and Patra, S (2009). Water Quality Profile of Yamuna River, India, Journal of Water, Energy and Environment ( Hydro Nepal). 3:19-24

Shivashankara, G. P., Ranga, k., Ramalingaiah and Manamohan Rao, (1999). Characterstics of bulk precipitation in industrial areas of Banglore city, Indian Journal of Environmental Health 41:229-239

Shreshtha, S., Kazama, F.,(2007). Assessment of surface water quality using multivariate statistical techniques: A case study of Fuji river basin, Japan. Journal of Environmental Modelling \& Software, 22(2007):464475

Sinha, D. K. and Saxena, Ritesh (2006). Statistical Assessment of Underground Drinking Water Contamination and effect of monsoon at Hasanpur , J.P. Nagar, Journal of Environmental Science \& Engineering.,48:157-164

Tait (2012). Nonmarket valuation of water quality by addressing spatially heterogeneous references using GIS and a random parameter log it model, Journal of Ecological Economics ., 75:15-21
Teng, Yanguo., Yang, Jie., Zuo, Rui., and Wang, Jinsheng (2011). Impact of Urbanization and Industrialization upon Surface Water Quality, A Pilot Study of Panzhihua Mining Town, Journal of Earth Science., 22(5):658-668

Trivedi, R. K., Goel, P. K., (1986). Chemical and Biological methods for water pollution studies, Environmental Publications

Tiwari, T.N., and Mishra, M(1985). A preliminary assignment of water quality index of major Indian rivers, Indian Journal of Environmental Protection $., 5(4): 276-279$

Venu and Madhuri, R. (2011). Ecological effect of urbanization on Swan river watershed district Una, Himachal Pradesh, International Journal of Pharmacy \& life Sciences., 2(50:723-729

Wang, Junying., Da, Liangjun., Song,Kun., and Li,Bai-Lian (2008). Temporal variations of surface water quality in urban, suburban and rural areas during rapid urbanization in Shanghai, Journal of Environmental Pollution., 152:387-393

Yong, Li., Rui-wei, Xu., Shui-ming, Zhang., Qiong,An., Wei,Jin., and Zeng-qiang, Duan (1998). Changes of surface water pollution of Suzhou region: A case study in Taicang County, China, Journal of Environmental Sciences., 10(3):282-290 